\title{
Footprint of Online Booking in Hotel Industry
}

\author{
K. P. Dayana, A. Joseph Xavier, J. Pradeepkandhasamy
}

\begin{abstract}
The present study "Footprint of Online Booking in Hotel Industry" is systematic and experiential in nature. The research depends on the examination observed through suitable sampling techniques among the customers preferring the classes of hotels for convenience. The facts have been composed through a planned interview schedule, equipped by the investigator. It contains matters related to demographic profile, socio economic records, customer particulars and impact of hotels on Lack of knowledge regarding improvement in the hotel sector, Overall Online infrastructure of hotels, How to handle the computers for the process of booking through online, Identify the price fluctuations for different category hotels on each item, Implementation on Online booking. . The outcome of the cram prove that the enumerated value is greater than both the table values the $\mathrm{HO}$ is rejected. Hence there is a correlation association among the Lack of knowledge regarding improvement in the hotel sector, Overall Online infrastructure of Hotels, How to handle the computers for the process of booking through online, Identify the price fluctuations for different category hotels on each item, Implementation on Online booking
\end{abstract}

Keywords: Customers, correlation, Hotel, online infrastructure.

\section{INTRODUCTION}

Long-ago, hoteliers have curved their center of attention to the significance of maintenance level in the society as it is compared to inn enlargement and workings, together with the ecological, fiscal and societal impact. The hotel segment has previously had a spectacular environmental crash through oomph and dampens utilization. Sustainable Development is a holistic concept based on a simple principle. It saves our money by declining expenses and fritter away. Encouraging on "green" surroundings is the recent scenario of today.

Over the few years, the usage of online booking system has been tremendously increased across the globe. It reaches all classes of people. With the smartest technology in their palm they are adopting the choice of online accommodation. In the current era, B2C (Business to Customer) application has changed the situation rapidly.

Tourists are ever more provoked by numerous measures and supporting e - techniques to the traveler diversity and making the booking also faster. It includes the certain factors for the sustainability of the hotel industries:

Revised Manuscript Received on December 09, 2019.

* Correspondence Author

Mrs. K.P. Dayana*, Assistant Professor, Department of Commerce (Professional Accounting), Ayya Nadar Janaki Ammal College (Autonomous), Sivakasi, Email: drizzlingdayana@gmail.com

Dr. A. Joseph Xavier, Assistant Professor, Post Graduate and Research Department of Commerce, Ayya Nadar Janaki Ammal College (Autonomous), Sivakasi, Email: josephxavieranjac@gmail.com

J. Pradeepkandhasamy, Department of Computer Applications, School of Computing, Kalasalingam Academy of Research and Education, India. Email: j.pradeepkandasamy@klu.ac.in

1. Quick adoption of choosing their own accommodation from their home actually lower the hotel's operating costs and their cost too. It also reduces the expenses and the resources are utilized in an effective manner.

2. Destinations rich in biodiversity are attractive places, appeal to quality customers, and offer scope for sustainability in recreational activities.

3. Employees are powerfully annoyed and work has been minimized. It also assists to augment worker yield and devotion, and can trim down personnel proceeds.

4. Inculcating excellent follow up for sustainability depicts that a lodge concern on the reputed business, and hold up from government, organization and local neighborhood.

5 . Hotels are one of the chief patrons of vigor, which tender visitors with lofty levels of placate, conveniences and facilities.

Online booking have seen a slow climb. The tourist takes pleasure in choosing the expediency method of reserving his own assets. Travelers are able to find a area of their picking and scenery, and can assign it with no wavering and no appeal. The dependency altitude on mediator esteems to limited time and quality of information. Speed and Convenience Travelers are able to look at belongings alongside to contrast the pros and cons.

\section{A. Sources of Data}

Both major and minor data are worn for the current learning. Minor data were unruffled from a mixture of books, magazine, reports and websites. Prime data were collected from the respondents to seek the online booking provision.

\section{B. Pre-Test}

The interview schedule for this study is constructed by the researcher with the help of the guide and by having discussion with few manufacturers'. After pre-testing, the interview schedules are modified in the light of experiences gained.

\section{Sampling Design}

The primary data are collected by the researcher from different categories of manufacturers'. It is very difficult to apply sampling method to collect the data. Hence, convenient sampling technique has been adopted. The primary data collected from 80 manufacturers' in the study area..

\section{Data Processing}

After the completion of collection of data, the filled in schedules are edited properly. The researcher records the data, which are collected from customers' as per the interview schedule.

Master table is prepared to sum up all the information contained in the interview schedules. With the help of the master table, classified tables are prepared and later they are taken for analysis. 


\section{REVIEW OF LITERATURE}

Mahadev (1967)., in his article, "Spatial Distribution of Hotel Industry in Mysore City”suggested various physical planning decisions modifying the spatial trend. He has also studied the location pattern of different temporal stages and the spatial structure of hotel industry in the city of Mysore.

Singh, T.V (1975)., in his study, "Tourism and Tourist Industry : New Heights", has assessed hotels capacity at twelve different locations of tourist importance in the State of Uttar Pradesh. It concentrates on the domestic tourists are neither choosey about accommodation nor they demand superior service. But the foreign tourists demand better quality hotels. As such, there is a shortage of accommodation in relation to foreign tourist.

Anand, M.M. (1976)., in his study, "Tourism and Hotel Industry in India" scrutinized the nature of this multidimensional tourist plan whose activities range from the provision of comfortable lodging to facilitating a visit to a national monument. He has examined the structure and working of the plan. He demonstrates that the hotels and other supplementary accommodation are the core of the plan. The first prerequisite for the development of hotel industry is the forecast of the future demand, which would mean information about the number and type persons who would be making use of the facilities. It is in terms of demand that the right supply, at right place, right time and at right price is to be built up. 37 Failure to take into account future demand means either accommodation bottlenecks, which may hit the tourist industry adversely, or excess accommodation, which would result in loss to hotel industry. The wrong allocation of limited resources for this purpose means that the whole economy is affected as these funds are denied to other developmental sectors.

Bhatia, A.K. (1978)., in his study, "Tourism in India History and Development - Principles and Practice", has made certain suggestion regarding the level of demand for accommodation services. He also suggests that while calculating the requirement of rooms, various variable are required to be considered like duration of stay of a tourist and occupancy rates of tourist accommodation. If the annual occupancy would be higher, then the number of rooms or beds required for the visitors would be high and vice versa.
Malkarnekar, G.S. (1979)., “Accounting System and Controls in Hotel Company", in a case study has observed that the accounting system of a company helps to show the true state of affairs in hotel industry. He also proposed that the management should use operating charts for various departments to show profit / loss of various sections during different quarters, revenues and various operating expenses of these departments shows their contribution to the net earnings of the company.

Krishnaswamy, J. (1980)., has suggested that in his article "Hotel Industry Needs Incentives", in order to develop tourism, a country has to provide hotels facility at various destinations. Further, he also stated the countries from which India used to attract tourist have shown a slowdown in the growth rate. The slowdown in the arrival of tourist traffic is due to factors like political disturbances, rise in fuel cost, inflation and recession are attributable to the slow growth rate of tourist arrivals.

Formica 1996, in his article, "A study of tourism and hospitality education in Europe and America" scrutinized programs and future trends. It was found that there was an association that props up the freedom of generosity learning from its occupational base to studious grassland of inquisition.

\section{DISCUSSION}

Table- I: Correlations

\begin{tabular}{|c|c|c|c|c|c|c|}
\hline & & $\begin{array}{l}\text { Lack of knowledge } \\
\text { regarding } \\
\text { improvement in } \\
\text { Hotel sector }\end{array}$ & $\begin{array}{l}\text { Overall Online } \\
\text { infrastructure of } \\
\text { hotels }\end{array}$ & $\begin{array}{l}\text { How to handle } \\
\text { the computers } \\
\text { for the process } \\
\text { of booking } \\
\text { through online }\end{array}$ & $\begin{array}{l}\text { Identify the price } \\
\text { fluctuations for } \\
\text { different category } \\
\text { hotels on each } \\
\text { item }\end{array}$ & $\begin{array}{l}\text { Implementation on } \\
\text { online booking }\end{array}$ \\
\hline \multirow{2}{*}{$\begin{array}{l}\text { Lack of knowledge } \\
\text { regarding improvement } \\
\text { in Hotel sector }\end{array}$} & $\begin{array}{l}\text { Pearson } \\
\text { Correlation }\end{array}$ & 1 & $.475^{* * *}$ & .128 & .125 & $.359^{* * *}$ \\
\hline & Sig. (2-tailed) & & .000 & .258 & .268 & .001 \\
\hline \multirow{3}{*}{$\begin{array}{l}\text { Overall Online } \\
\text { infrastructure of hotels }\end{array}$} & $\begin{array}{l}\text { Pearson } \\
\text { Correlation }\end{array}$ & $.475^{* *}$ & 1 & $.254^{*}$ & .204 & $.407^{* * *}$ \\
\hline & Sig. (2-tailed) & .000 & & .023 & .070 & .000 \\
\hline & $\mathrm{N}$ & 80 & 80 & 80 & 80 & 80 \\
\hline \multirow{2}{*}{$\begin{array}{l}\text { How to handle the } \\
\text { computers for the } \\
\text { process of booking }\end{array}$} & $\begin{array}{l}\text { Pearson } \\
\text { Correlation }\end{array}$ & .128 & $.254^{*}$ & 1 & $.474^{\text {*** }}$ & .138 \\
\hline & Sig. (2-tailed) & .258 & .023 & & .000 & .224 \\
\hline
\end{tabular}




\begin{tabular}{|c|c|c|c|c|c|c|}
\hline through online & $\mathrm{N}$ & 80 & 80 & 80 & 80 & 80 \\
\hline \multirow{2}{*}{$\begin{array}{l}\text { Identify the price } \\
\text { fluctuations for different } \\
\text { category hotels on each } \\
\text { item }\end{array}$} & $\begin{array}{l}\text { Pearson } \\
\text { Correlation }\end{array}$ & .125 & .204 & $.474^{* * *}$ & 1 & $.400^{* * *}$ \\
\hline & Sig. (2-tailed) & .268 & .070 & .000 & & .000 \\
\hline \multirow{2}{*}{$\begin{array}{l}\text { Implementation } \\
\text { online booking }\end{array}$} & $\begin{array}{l}\text { Pearson } \\
\text { Correlation }\end{array}$ & $.359^{* *}$ & $.407^{* *}$ & .138 & $.400^{* * *}$ & 1 \\
\hline & Sig. (2-tailed) & .001 & .000 & .224 & .000 & \\
\hline
\end{tabular}

Positive significant correlation is observed between lack of knowledge regarding improvement in Hotel sector and overall online infrastructure of hotels $(r=.475)$. Hence the null hypothesis "There is no noteworthy relationship between lack of knowledge improvement in Hotel sector and overall online infrastructure of hotels" is rejected at $1 \%$ level. This shows that overall online infrastructure of hotels by the lack of knowledge regarding improvement in hotel sector

Positive significant correlation is observed between Overall Online infrastructure of hotels and How to handle the computers for the process of booking through online ( $\mathrm{r}$ $=.254$ ). Hence the unsound hypothesis "There is no major relationship among Overall Online infrastructure of hotels and How to handle the computers for the process of booking through online" is rejected at $1 \%$ level. This shows that How to handle the computers for the process of booking online by overall online infrastructure of hotels.

Positive significant correlation is observed between How to handle the computers for the process of booking through online and Identify the price fluctuations for different category hotels on each item $(r=.474)$. Hence the null hypothesis "There is no significant relationship between How to handle the computers for the process of booking through online and Identify the price fluctuations for different category hotels on each item is rejected at $1 \%$ level. This shows that identify the price fluctuations for different category hotels on each item by How to handle the computers for the process of booking through online

Positive significant correlation is observed between Implementation on online booking and Identify the price fluctuations for different category hotels on each item ( $\mathrm{r}$ $=.474$ ). Hence the null hypothesis "There is no significant relationship between Implementation on online booking and Identify the price fluctuations for different category hotels on each item is rejected at $1 \%$ level. This shows that Implementation on online booking and Identify the price fluctuations for different category hotels on each item.

\section{CONCLUSION}

The study has revealed the individual data, socio economic data, customers minutiae and impact of online booking on lack of knowledge regarding improvement in Hotel sector and overall online infrastructure of hotels, How to handle the computers for the process of booking through online, Identify the price fluctuations for different category hotels on each item. The outcome of the work illustrates that the calculated cost is more than both the counter values the $\mathrm{H} 0$ is redundant. Hence there is a correlation bond flanked by the lack of knowledge regarding improvement in Hotel sector, overall online infrastructure of hotels, How to handle the computers for the process of booking through online; Identify the price fluctuations for different category hotels.

\section{REFERENCES}

1. Mahadev, P.D. (1967): "Spatial Distribution of Hotel Industry in Mysore City", National Geographical Journal of India, Vol.II, No.4 December.

2. Singh, T.V. (1975): "Tourism and Tourist Industry : New Heights", p.152-173.

3. Anand, M.M.(1976): "Tourism and Hotel Industry in India", Prentice-Hall of India, New Delhi, p.I.

4. Bhatia, A.K. (1978): "Tourism in India History and Development Principles and Practice", Sterling Publications, New Delhi.

5. Malkarnekar, G.S. (1979): "Accounting System and Controls in Hotel Company”, in: 'The Chartered Accountant', August, pp.153-156.

6. Krishnaswamy, J. (1980): "Hotel Industry Needs Incentives", in: 'Commerce', 17th May, 1980.

7. Dharmarajan (1981): "Hoteleering in the Public Sector", in: 'Indian and Foreign Trade Review', Vol.19(2), 16th November, 1981.

8. Agarwal, S., Krishna E.M., S. Dev, C. (2003), "Market Orientation and Performance in service firms: role of innovation ", Journal of Services Marketing, Vol. 17, No. 1.

9. Brooker, E., Joppe, M., Davidson, M.C.G. and Mules, K. (2012), "Innovation within the Australian outdoor hospitality parks industry", International journal of Contemporary Hospitality Management, Vol. 24, No.5

\section{AUTHORS PROFILE}

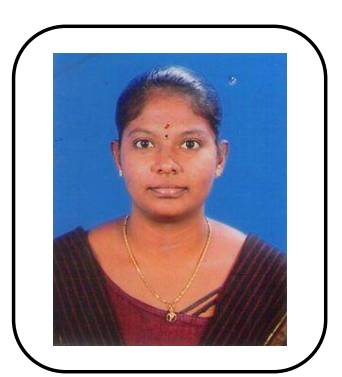

Mrs. K. P .Dayana, Assistant Professor, Department of Commerce (Professional Accounting), Ayya Nadar Janaki Ammal College (Autonomous), Sivakasi have 4years of Teaching Experience. She completed her under graduation, Master degree and Master of Philosophy in The Standard Fireworks Rajarathnam College for Women, Sivakasi. Her major research area is marketing.

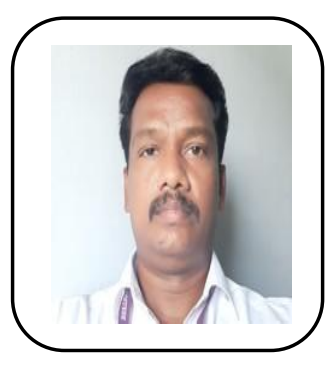

Dr. A. Joseph Xavier, Assistant Professor, Post Graduate and Research department of Commerce, Ayya Nadar Janaki Ammal College (Autonomous), Sivakasi have 16 years of Teaching Experience. He has completed his under graduation, Master degree and Master of Philosophy in Ayya Nadar Janaki Ammal College (Autonomous), Sivakasi. He has completed his doctorate in Madurai Kamaraj University. His major research area is

Finance, Marketing and HRM. 


\section{Footprint of Online Booking in Hotel Industry}

Mr. J. Pradeepkandhasamy, Assistant Professor, Department of Computer Applications, Kalasalingam Academy of Research and Education have more than 7 years of Teaching Experience. He completed his Under Graduation in Computer Science at Bharathidasan University and Post Graduation in Master of Computer Applications in

Kalasalingam University, His Major research area is prediction and classification in Data Mining. 